University of Nebraska - Lincoln

DigitalCommons@University of Nebraska - Lincoln

Management Department Faculty Publications

Management Department

2009

Inquiry Unplugged: Building on Hackman's Potential Perils of POB

Fred Luthans

University of Nebraska-Lincoln, fluthans1@unl.edu

Bruce Avolio

University of Washington

Follow this and additional works at: https://digitalcommons.unl.edu/managementfacpub

Part of the Management Sciences and Quantitative Methods Commons

Luthans, Fred and Avolio, Bruce, "Inquiry Unplugged: Building on Hackman's Potential Perils of POB" (2009). Management Department Faculty Publications. 20.

https://digitalcommons.unl.edu/managementfacpub/20

This Article is brought to you for free and open access by the Management Department at DigitalCommons@University of Nebraska - Lincoln. It has been accepted for inclusion in Management Department Faculty Publications by an authorized administrator of DigitalCommons@University of Nebraska - Lincoln. 
Published in Journal of Organizational Behavior 30 (2009), pp. 323-328; doi 10.1002/job.590

Copyright $@ 2009$ John Wiley \& Sons, Ltd. Used by permission. http://www.interscience.wiley.com

Accepted for publication November 10, 2008

Point / Counterpoint

\title{
Inquiry Unplugged: Building on Hackman's Potential Perils of POB
}

\author{
Fred Luthans ${ }^{1}$ and Bruce J. Avolio ${ }^{2}$ \\ ${ }^{1}$ University of Nebraska-Lincoln, Lincoln, Nebraska, U.S.A. \\ ${ }^{2}$ University of Washington, Seattle, Washington, U.S.A. \\ Corresponding author - F. Luthans, Department of Management, University of Nebraska-Lincoln, \\ Lincoln, NE 68588-0491, U.S.A; email fluthans1@unl.edu
}

\begin{abstract}
In this rejoinder to Hackman's counterpoint piece on positive organizational behavior (POB), we again take a positive, inquiry approach. We address and build out each of his identified potential perils with the aim of accelerating the journey of $\mathrm{POB}$ understanding, research, and application.
\end{abstract}

\section{Introduction}

We are pleased to be able to follow-up on Richard Hackman's article on "The Perils of Positivity." We especially appreciate this opportunity because his thoughtful article has enabled us to continue in our perspective and approach taken in our preceding "Point of Positive Organizational Behavior" article. Specifically, Hackman's points about the potential perils of positive organizational behavior or POB allow us to remain positive and in an inquiry mode rather than take a defensive, advocacy position. How? In his article, he raises some very important and critical points for any emerging area of theoretical and research interest to consider. Indeed, we agree with most of his identified areas of concern, that in his words, "were prompted by reading the papers in this issue (italics added)" and that he indicates were not intended to be a "comprehensive assessment of the rapidly expanding field of positive organizational behavior." In other words, we do not feel the need to refute, correct, or defend the points he makes as they are well taken. Instead, we can begin to address and even provide support for his points from our own and others work in POB that is not limited to the papers in this issue.

To set the tone for this follow-up article, we would like to jump right to Hackman's closing comments on the need for "the highest possible standards for positive organizational behavior research." This is precisely the focus we endorse and have encouraged in others for all of the work in POB. Specifically, in dealing with the inevitable "tension" he refers to in advancing a focus on POB, we fully support the need for a sound theoretical basis and understanding, operational definitions, accepted (and new) research methodologies, and valid measures. This is why from the very beginning we have defined and taken a strong stance that POB research must adhere to the highest scientific standards for developing theory and validation of these theories (see, Luthans, 2002a). 
From the outset, we have tried to encourage all those working in or contemplating work in POB to concentrate on providing sound theoretical grounding (Luthans, Youssef, \& Avolio, 2007), while also establishing the validity of the theory-driven constructs and measures used in research on POB (see, e.g., Luthans, Avolio, Avey, \& Norman, 2007). Consequently, using our full endorsement of Hackman's call for the highest standards as a point of departure, we will structure this article to address most of his identified "Perils" and emphasize where we feel further inquiry is necessary.

\section{The Impetus for POB}

The first question that Hackman raises is that, unlike the impetus for positive psychology, POB did not really need to start by reacting to organizational negativity and pathologies. Although the impetus and foundation for POB is largely derived from the positive psychology literature, especially in terms of its demand for theory, research, and valid measurement (Cameron, Dutton, \& Quinn, 2003; Luthans, 2002a; Luthans \& Youssef, 2007; Peterson \& Seligman, 2003; Wright, 2003), we would like to highlight here how POB differs, as well as where it builds upon the foundations of both positive psychology and organizational behavior. In particular, we note in the first Point article that "the field of organizational behavior has been more positive than psychology in general, and, of course, for sure clinical psychology" and "OB tends to be more positive than negative."

There is recent quantitative evidence, at least in certain subfields in $\mathrm{OB}$, that negative phenomena as a point of interest to researchers may in some ways dominate over the positive, for example, in much of the popular business press and a number of organizational studies (see Margolis \& Walsh, 2003) and articles published in both The Journal of Applied Behavioral Science (Cameron, 2008) and the Journal of Occupational Health Psychology (Schaufeli \& Salanova, 2007). However, we do agree with Hackman that POB should not be misconstrued as being propelled by, in his words, "correcting a historical over-emphasis on pathologies." Our previous Point piece notes that POB does recognize the considerable past, present, and future of positive constructs in OB, but at the same time attempts to concentrate on underrepresented positive constructs (e.g., hope, resilience, courage, and wisdom from clinical, developmental, and social psychology or even the heliotropic effect from biology) and an overall focus in terms of metaphorically building a new "restaurant" to house the old and new positive "wine" and "wine bottles."

\section{POB's Level of Analysis}

We would also like to build-out Hackman's main concern for POB's seeming over-emphasis on the individual level of analysis. Remembering again that he is reacting to the articles in this special issue, as opposed to the broader body of literature, we would like to first note in the growing workplace literature focusing on positivity, the use of the terminology POB is clearly differentiated from what is called positive organizational scholarship (POS, e.g., see Luthans \& Youssef, 2007 for a review of this literature). Hackman understandably tends to use these two terms interchangeably. However, although there are certainly similarities, there are also some recognized differences. Specifically, POB and the POS initiative begun at the University of Michigan (e.g., see Cameron, 2008; Cameron \& Caza, 2004; Cameron et al., 2003) are definitely similar in terms of positivity and scholarship, but to date, there have been some clear differences with respect to operationally defining the constructs focused upon (e.g., POS-compassion, gratitude, forgiveness, relationships, energy; POB-hope, optimism, efficacy, ownership, wellness, engagement; and some in both such as re- 
silience, strengths, and emotions). Moreover, there have been differences in terms of the focus on levels of analysis, which we endorse as being extremely important at the outset of developing an emerging area of theoretical and research interest. One example is the distinction that Luthans and Avolio (2003) made when talking about a positive ethical climate in their foundational model on authentic leadership development.

Besides this seeming less important difference in the choices of what constructs are studied, in terms of the perils of not considering the constructs at multiple levels, are the more important level of analysis distinctions between POB and POS. So far, POB has tended to develop in an inductive way from individual (as largely represented in this special issue and most of the research to date such as Luthans, Avolio, et al., 2007) to group (see the West, Patera and Carsten article in this issue), to organizational (see Avey, Wernsing, \& Luthans, 2008 on positive organizational change) levels of analysis. On the other hand, a lot of the work in the area of POS has tended to be the reverse, going from organizational to group to individual levels, but both approaches showing attention to specifying levels of focus and analysis. For example, Cameron and Caza (2004) emphasize levels when describing that POS is mainly concerned with interpersonal and structural dynamics, "the context in which the positive phenomena occur" (p. 731). Also by way of example and emphasis, Cameron and Lavine (2006, p. 8) in the conceptual foundation for POS note that, "the organization is motivated to change from being profitable, effective, efficient, or reliable in performance, for example, to being extraordinary, flawless, generous, or benevolent" with a number of empirical POS studies focusing on the organizational level (e.g., Bright, Cameron, \& Caza, 2006; Cameron, 2003; Cameron, Bright, \& Caza, 2004).

Although not to the extent of POS per se, both multi-level theory building (e.g., see Youssef \& Luthans, 2005, in press) and examining behavior in context research (e.g., see Luthans, Norman, Avolio, \& Avey, 2008) are also recognized in the literature associated with POB. For example, our initial model of authentic leadership development noted above draws equally from POB and the organization context (Avolio \& Luthans, 2006; Luthans \& Avolio, 2003). In other words, even though this special issue may appear to be weighted too heavily at the individual level, and our own inductive research in developing the measures and testing theory-driven hypotheses has also started at the individual level, further inquiry into the broader literature clearly indicates the POS approach is more focused at the organizational level, while many of the published and in process POB studies are at the team and organizational levels of analysis. In fact, as a takeoff from Ben Schneider's widely quoted "the people make the place" we would even put forth the argument that "context make the people." We could not agree more with Hackman's point of going beyond just the individual level, but we would add we should study from genes to culture and everything that interacts in between (including the individual) in order to build-out the science of POB.

\section{Addressing Other Potential Perils Through Inquiry}

We have tried to model above how we can transform perils into positives by staying largely in an inquiry mode. In the remaining space available, we will, in a briefer way, address some of Hackman's other points in a similar inquire and build manner.

\section{POB being ahistorical}

As we carefully suggest in our Point article in this special issue, and of course what positive psychology is constantly questioned about, the writings associated with POB have been careful not to 
claim that focusing on positivity is something new to the literature. Also, the long and rich history of the $\mathrm{OB}$ field has been repeatedly recognized from the very early inception of work on POB. For example, as we pointed out, the first sentence in the article introducing POB states: "Since the very beginning of the academic field of organizational behavior (OB) at the Hawthorne Works of the Western Electric Company, a clear relationship between positive feelings of employees and their performance has been recognized" (Luthans, 2002b, p. 57).

Now over 6 years later, the historical precedents in most of the articles in this issue, and we would add in the OB field in general, may not provide the full historical reference base given the need to explain novel constructs at the expense of reviewing the broad literature from which these constructs have emerged. However, we would point out that most of the constructs studied in POB have historical grounding in other fields than OB (e.g., resiliency and hope from clinical psychology). However, we support and recommend that others heed Hackman's call for more historical foundation in POB as an emerging area of interest.

\section{POB meeting scientific criteria}

As already noted, we could not agree more with this most pervasive peril expressed by Hackman. Once again, this need for a scientific basis for POB was the major theme of our Point piece and our explicit criterion for inclusion in what we mean by POB (see Luthans, 2002a; Luthans, Youssef, et al., 2007). From this point, we want to acknowledge Hackman's great examples of the importance of the scientific process and would simply build on them for POB. For example, we would agree that more constructs do not mean better constructs and that is why we have tried to only include existing positive constructs that have an historical base, and have met established scientific criteria for theory, research, and measurement, and when taken to the workplace have been put to the stringent tests of construct validation (e.g., see Luthans, Avolio, et al., 2007).

We would also add as an aside, to meet Hackman's concerns for direction of causality, explanatory mechanisms, and dimensionality of concepts, the dissertations of all doctoral students in our leadership program here at the University of Nebraska (see gli.unl.edu) must involve an experimental intervention and the same is true of the major project required of MBA students in our executive leadership programs. Indeed, we have gone so far as to ask them to calculate the Return on Development Investment or (RODI) for their intervention projects. Moreover, in our own current work, we are using multiple methods (including new "mixed methods") in our pursuit of increasingly complex and multilevel research questions and are encouraging similar approaches among colleagues who have worked with us. For example, we have studies in various stages examining the impact of POB and authentic leadership constructs at individual, team, and organizational level outcomes in financial, prison, police, military, health care, university operations, manufacturing, and international samples with many of these studies using mixed methods strategies, longitudinal analysis and experimental manipulations.

\section{Some cautions to heed in newly emerging fields such as $P O B$}

The final perils raised by Hackman seem more directed toward any emerging and potentially new paradigms, but certainly apply to POB as well. Specifically, again using examples from other fields of study, including his own work with Greg Oldham on job design, he properly warns the POB field of the following:

- Making the best of a bad situation (through positivity in the case of POB) is not enough. What Hackman means by this is that although those working in the POB area may have noble reasons for 
helping employees get through the bad situations they find themselves in today's organizations, we should not forget to give at least as much attention to the positive organizational conditions that already have been shown to promote learning and growth. We interpret his comments as recommending that POB researchers should be giving relatively more attention to the organizational level of analysis. As we covered earlier, we feel this is being done, especially in POS and in a lot of the new work on POB. We envision the POB and POS literatures becoming increasingly more integrated into the future.

- POB should not become seduced by the trappings of new paradigm development. What we interpret Hackman to mean here is that those of us working in the area of POB should not make the mistakes that are strewn throughout the literature concerning previous "new" developments. Again by way of offering some great historical examples, he cautions that POB should not become over-reliant on our early, preferred models and methods that stifle innovation and progress. The same for scholarly standards; they should never be relaxed or compromised in order to "spread the gospel." Once again, we completely agree. Although we are unabashedly enthusiastic and passionate about our work in $\mathrm{POB}$, and as we said in our Point piece having fun along the way, we fully realize the sustainable contribution that $\mathrm{POB}$ may make to the human enterprise is only as good as our scientific process in trying to answer the important research questions, testing our theory-driven hypotheses, and drawing valid evidence-based guidelines for practice. In fact, our leadership institute here at the University of Nebraska has made it a central part of its mission to demand evidence-based leadership development, which we have referred to as "authentic" leadership development to symbolize our commitment to Hackman's call for high research standards. It should also be noted that all of our models have evolved over time, as others have challenged them, and indeed have facilitated improving their predictions.

In conclusion, we hope this exchange of ideas about where we are and where we need to go in POB has made us all smarter and wiser. Clearly, using Hackman's challenges as a means for promoting inquiry into our thinking has affected our responses found in this short article. Finally, we would like to publically thank this Journal of Organizational Behavior special issue editors Tom Wright and Jim Quick for allowing us to hopefully keep going in the right direction in the journey of building out POB that so far seems to show a great deal of promise for augmenting the broad base of knowledge accumulated over the decades in $\mathrm{OB}$ and related fields of positive psychology.

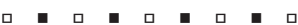

Fred Luthans is the George Holmes Distinguished Professor of Management in the Department of Management, University of Nebraska-Lincoln. A past president of the Academy of Management and editor of three journals, his current research revolves around positive organizational behavior and psychological capital.

Bruce J. Avolio is the Marion B. Ingersoll Professor of Management at the Foster School of Business at the University of Washington. His current research interests include authentic leadership, leadership development and psychological capital. 


\section{References}

Avey, J. B., Wernsing, T. S., \& Luthans, F. (2008). Can positive employees help positive organizational change? The Journal of Applied Behavioral Science, 44, 7-24.

Avolio, B. J., \& Luthans, F. (2006). The high impact leader: Moments matter in accelerating authentic leadership development. New York: McGraw-Hill.

Bright, D. S., Cameron, K. S., \& Caza, A. (2006). The amplifying and buffering effects of virtuousness in downsized organizations. Journal of Business Ethics, 64, 249-269.

Cameron, K. S. (2003). Organizational virtuousness and performance. In K. S. Cameron, J. Dutton, \& R. E. Quinn (Eds.), Positive organizational scholarship (pp. 48-65). San Francisco: Berrett-Koehler.

Cameron, K. S. (2008). Paradox in positive organizational change. The Journal of Applied Behavioral Science, 44, 7-24.

Cameron, K. S., \& Caza, A. (2004). Contributions to the discipline of positive organizational scholarship. American Behavioral Scientist, 47, 731-739.

Cameron, K. S., \& Lavine, M. (2006). Making the impossible possible: Leading extraordinary performance - The Rocky Flats story. San Francisco: Berrett-Koehler.

Cameron, K. S., Dutton, J., \& Quinn, R. (Eds.). (2003). Positive organizational scholarship. San Francisco: Berrett-Koehler.

Cameron, K. S., Bright, D., \& Caza, A. (2004). Exploring the relationships between organizational virtuousness and performance. American Behavioral Scientist, 47, 766-790.

Luthans, F. (2002a). The need for and meaning of positive organizational behavior. Journal of Organizational Behavior, 23, 695-706.

Luthans, F. (2002b). Positive organizational behavior: Developing and managing psychological strengths. Academy of Management Executive, 16, 57-72.

Luthans, F., \& Avolio, B. J. (2003). Authentic leadership development. In K. S. Cameron, J. E. Dutton, \& R. E. Quinn (Eds.), Positive organizational scholarship (pp. 241-258). San Francisco: Berrett-Koehler.

Luthans, F., \& Youssef, C. M. (2007). Emerging positive organizational behavior. Journal of Management, 33, 321-349.

Luthans, F., Avolio, B., Avey, J., \& Norman, S. (2007). Positive psychological capital: Measurement and relationship with performance and satisfaction. Personnel Psychology, 60, 541-572.

Luthans, F., Youssef, C. M., \& Avolio, B. J. (2007). Psychological capital: Developing the human competitive edge. Oxford, UK: Oxford University Press.

Luthans, F., Norman, S. M., Avolio, B. J., \& Avey, J. B. (2008). The mediating role of psychological capital in the supportive organizational climate-employee performance relationship. Journal of Organizational Behavior, $29,219-238$.

Margolis, J. D., \& Walsh, J. P. (2003). Misery love companies: Rethinking social initiatives by business. Administrative Science Quarterly, 48, 268-305.

Peterson, C. M., \& Seligman, M. E. P. (2003). Positive organizational studies: Lessons from positive psychology. In

K. S. Cameron, J. E. Dutton, \& R. E. Quinn (Eds.), Positive organizational scholarship (pp. 14-27). San Francisco: Berrett-Koehler.

Schaufeli, W., \& Salanova, M. (2007). Work engagement. In S. W. Gilliland, D. D. Steiner, \& D. P. Skarlicki (Eds.). Managing social and ethical issues in organizations (pp. 135-177). Charlotte, NC: Information Age Publishing.

Wright, T. A. (2003). Positive organizational behavior: An idea whose time has truly come. Journal of Organizational Behavior, 24, 437-442.

Youssef, C. M., \& Luthans, F. (2005). Resiliency development of organizations, leaders and employees: Multilevel theory building for sustained performance. In W. Gardner, B. Avolio, \& F. Walumbwa (Eds.), Authentic leadership theory and practice (pp. 303-343). Oxford, UK: Elsevier.

Youssef, C. M., \& Luthans, F. (in press). An integrated model of psychological capital in the workplace. In P. A. Linley (Ed.), Handbook of positive psychology and work. Oxford, UK: Oxford University Press. 